\title{
Consumption of industrialized food by infants attending child day care centers
}

\author{
Consumo de alimentos industrializados por lactentes matriculados em creches \\ Consumo de alimentos industrializados por lactantes matriculados en guarderías
}

Maysa Helena de A. Toloni', Giovana Longo-Silva², Tulio Konstantyner ${ }^{3}$, José Augusto de A. C. Taddei

\section{ABSTRACT}

Objective: To identify the age of introduction of petit suisse cheese and instant noodles in the diet of infants attending nurseries of public day care centers and to compare the nutritional composition of these foods with the healthy recommended diet (breast milk and salt meal) for this age, in order to estimate nutritional errors.

Methods: Cross-sectional study of 366 children (from nine to 36 months old) who attended day care centers, whose mothers were interviewed about the age of introduction of those foods. The means of the nutrients indicated on the labels of the most consumed brands were considered. For the calculation of the percent composition of breast milk and salt meal, Tables of Food Composition were used. To assess the nutritional adequacy, we used the Dietary Reference Intakes by age group. The percentage of adequacy evaluation of the petit suisse cheese and the instant noodles nutritional compositions was made by comparing them with those of the human milk and the salt meal, respectively.

Results: The petit suisse cheese and the instant noodles were consumed by 89.6 and $65.3 \%$ of the children in the first year of life. The percentages of adequacy for carbohydrates were more than twice and the percentages for sodium were 20 times higher than those found in the recommended foods.

Conclusions: Both industrialized products are inappropriate for infants, emphasizing the need for adoption of

Instituição: Disciplina de Nutrologia do Departamento de Pediatria da Universidade Federal de São Paulo (Unifesp), São Paulo, SP, Brasil

${ }^{1}$ Unifesp, São Paulo, SP, Brasil

2Faculdade de Nutrição da Universidade Federal de Alagoas (UFAL), Maceió, AL, Brasil

${ }^{3}$ Universidade de Santo Amaro (Unisa), São Paulo, SP, Brasil

${ }^{4}$ Unifesp, São Paulo, SP, Brasil norms that can inform health professionals, educators and parents about the risks of consumption.

Key-words: industrialized foods; food habits; food consumption; child day care centers; infant.

\section{RESUMO}

Objetivo: Identificar a idade de introdução do queijo petit suisse e do macarrão instantâneo na dieta de lactentes matriculados em berçários de creches públicas/filantrópicas e comparar suas composições nutricionais com a alimentação recomendada para a idade (leite materno e refeição salgada), visando estimar erros nutricionais.

Métodos: Estudo transversal com 366 crianças (de nove a 36 meses) de berçários de creches, cujas mães foram entrevistadas sobre idade de introdução dos alimentos. Consideraram-se as médias de nutrientes indicadas nos rótulos das marcas mais consumidas. No cálculo da composição centesimal do leite materno e da refeição salgada, utilizaram-se Tabelas de Composição de Alimentos. Para avaliação da adequação nutricional, utilizaram-se as Recomendações de Ingestão Diária por faixa etária. A avaliação dos percentuais de adequação das composições nutricionais do petit suisse e do macarrão instantâneo foi feita comparando-as com as do leite materno e da refeição salgada, respectivamente.

Endereço para correspondência:

Maysa Helena de A. Toloni

Rua Loefgreen, 1.647 - Vila Clementino

CEP 04040-032 - São Paulo/SP

E-mail: maysatoloni@yahoo.com.br

Fonte financiadora: Fundação de Amparo à Pesquisa do Estado de São Paulo (Fapesp) - processo n 2006/02597-0; ABBOTT Nutrition; MHAT e GL foram bolsistas de doutorado Capes (Coordenação de Aperfeiçoamento de Pessoal de Nível Superior); TK foi bolsista de pós-doutorado Fapesp e JAACT é bolsista de produtividade CNPq.

Conflito de interesse: nada a declarar

Recebido em: 12/6/2013

Aprovado em: 8/9/2013 
Resultados: O petit suisse e o macarrão instantâneo foram consumidos por 89,6 e 65,3\% dos lactentes ainda no primeiro ano de vida. Os percentuais de adequação para carboidrato foram superiores a duas vezes o recomendado e os percentuais de sódio, 20 vezes superiores aos encontrados nos alimentos recomendados.

Conclusões: Os dois produtos industrializados são impróprios para lactentes, ressaltando-se a necessidade de adoção de normatização que possa informar os profissionais de saúde, os educadores e os pais sobre os riscos do consumo.

Palavras-chave: alimentos industrializados; hábitos alimentares; consumo de alimentos; creches; lactente.

\section{RESUMEN}

Objetivo: Identificar la edad de introducción del queso petit suisse y de la pasta instantánea en la dieta de lactantes matriculados en nidos de guarderías públicas/filantrópicas y comparar sus composiciones nutricionales con la alimentación recomendada para la edad (leche materna y comida salada), con el objetivo de estimar errores nutricionales.

Métodos: Estudio transversal con 366 niños (de nueve a 36 meses) de nidos de guarderías, cuyas madres fueron entrevistadas sobre la edad de introducción de los alimentos. Se consideraron los promedios de nutrientes indicados en los rótulos de las marcas más consumidas. En el cálculo de la composición centesimal de la leche materna y de la comida salada se utilizaron las Tablas de Composición de Alimentos. Para evaluación de la adecuación nutricional, se utilizaron las Recomendaciones de Intesta Diaria por franja de edad. La evaluación de los porcentajes de adecuación de las composiciones nutricionales del petit suisse y de la pasta instantánea se hizo comparándolas con las de la leche materna y de la comida salada, respectivamente.

Resultados: El petit suisse y la pasta instantánea fueron consumidos por 89,6 y $65,3 \%$ de los lactantes todavía en el primer año de vida. Los porcentajes de adecuación para carbohidrato fueron superiores a dos veces lo recomendado y los porcentajes de sodio, 20 veces superior a los encontrados en los alimentos recomendados.

Conclusiones: Los dos productos industrializados son impropios para lactantes, subrayándose la necesidad de adopción de normatización que pueda informar a los profesionales de salud, los educadores y los padres sobre los riesgos del consumo.

Palabras clave: alimentos industrializados; hábitos alimentares; consumo de alimentos; guarderías; lactantes.

\section{Introduction}

In the last decades, there have been changes in the eating habits of the population, especially regarding the replacement of natural foods and homemade foods for processed foods, which are high energy-dense and present low nutritional quality. The influences of the advertising market, globalization, the fast pace of life in big cities, women's work outside the home, and the economic and social development contributed to these changes ${ }^{(1-5)}$.

The theory of the developmental origin of health and disease and the evidence of knowledge in epigenetics demonstrate that damages suffered in the early stages of development, due to the early introduction of obesogenic diets, have long-term effects on the health of infants, being directly associated to predisposition for obesity and noncommunicable chronic diseases (NCCDs) $)^{(6,7)}$.

The current obesogenic environment, in which the introduction of processed foods occurs in the first months of life, is characterized by the increase in the worldwide consumption of processed foods, motivated by marketing strategies developed by multinational companies that invest heavily in advertising high-energy products for children and adolescents $^{(2,8)}$. Among these foods, stand out those consumed early in life, which are being progressively introduced in the food market over the past decades. The petit-suisse cheese (PSC) and the instant noodles (IN) are examples of these types of foods. These products had an accelerated insertion, with consumption increase in the food market due to extensive advertising campaigns strategically directed to children, as well as factors such as palatability and practicality, which inserted them and kept them on the eating habits of the population, including children under 1 year of life $\mathrm{f}^{(4,9)}$.

The aim of this study was to identify the age of introduction of these two processed foods, PSC and IN, in the diet of children attending public/philanthropic daycare centers and to compare the nutritional composition of these products with the healthy diet recommended for their age, with the objective to quantify nutrition errors.

\section{Method}

The present study was developed in seven public and philanthropic daycare centers within the Coordination of Education of Santo Amaro in the municipality of São Paulo, which were part of the project "Projeto Crecheficiente - Impacto do treinamento de educadores de creches públicas/filantrópicas nas práticas higiênico-dietéticas e na saúde/nutrição dos lactentes (Impact of training educators in public/philanthropic 
daycare centers on hygiene and dietary practices and on infant health and nutrition)". The process of selection of the daycare centers and the criteria used are described in another publication ${ }^{(10)}$.

This was a cross-sectional study, whose population comprised 389 children of both sexes, with age range from 9 to 26 months, who attended daycare centers regularly and where authorized by parents or guardians to participate in the study by signing the informed consent form. Children whose parents/guardians refused to sign the consent form $(n=2)$, those who were not present present on the day of data collection $(n=3)$, and those without data for the selected variables $(\mathrm{n}=18)$ were excluded, with a total sample loss of $5.9 \%$ and a final sample of 366 children.

The introduction of two foods, PSC and IN, was evaluated from data collected through a structured, pre-coded, and pretested questionnaire regarding their validities of content and construct, which included open and closed questions regarding socioeconomic data, maternal indicators, and infant feeding practices. For both analyzed foods, the age was registered in months of introduction. Data collection was conducted in the second semester of 2010 by four properly trained nutritionists, which interviewed parents or guardians in the daycares, in previously scheduled days.

In order to standardize the completion of this instrument, we prepared an interviewer manual with guidelines and coding of variables. We analyzed data regarding internal consistency, followed by double entry and validation. Statistical analysis was conducted with the program Epi-Info $2000^{(11)}$.

The proximate compositions of the petit-suisse cheese and the instant noodles were evaluated comparing them with those of breast milk and the savory meal respectively, as recommended by the Brazilian Society of Pediatrics (BSP) and the Brazilian Ministry of Health (MS) ${ }^{(12,13)}$. To define the chemical composition of processed foods, we used the means of the nutritional information displayed on the labels of the five most consumed brands for each of the two products. The proximate compositions of the savory meal and the breast milk were obtained by consulting the Tables of Food Composition ${ }^{(14,15)}$. Subsequently, we used the Recommended Daily Intake (RDI) ${ }^{(16,17)}$ to define adequacy percentages for the three age groups $(0-6,7-12$, and 12-36 months) regarding the proximate composition of the four foods, including values for energy, protein, fat, carbohydrate, calcium, iron, and sodium. Finally, the adequacy percentage obtained for the PSC and the IN were respectively compared with the adequacy percentage of breast milk and the savory meal, considering the adequacies by age group of the latter as $100 \%$.

The present study was approved by the Research Ethics Committee of Universidade Federal de São Paulo (Unifesp).

\section{Results}

The mean age of children in this study was $24 \pm 6.1$ months. Of the total number of children analyzed ( $\mathrm{n}=366)$, there was a predominance of males $(53 \%)$ and a higher proportion of mothers in the age range of $20-35$ years, with a mean age of $28 \pm 6.5$ years. Regarding maternal education, we found that $36.3 \%$ of mothers had less than 8 years of study.

Table 1 shows the cumulative frequency (\%) according to the age of introduction of PSC and IN, as well as the mean and standard deviation of the age of introduction. It is observed that, about half the children in this study was fed with PSC until the end of the 6th month of life. In relation to the IN, it is observed that it was consumed before the first year of life by $65.3 \%$ of children.

Table 2 shows the nutritional composition of breast milk, PSC, IN, and the savory meal, as well as the adequacy percentage of these four foods, according to the RDI of nutrients by age range. The percentage inadequacies of sodium in processed foods can be highlighted, especially in the age ranges from $0-6$ and $7-12$ months, reaching more than $1,000 \%$ adequacy, according to the RDI.

Figures 1 and 2 show the adequacy percentages obtained for the PSC and the IN when compared with the adequacy percentages of breast milk and the savory meal respectively, considering the different age ranges and highlighting the adequacy of foods recommended as $100 \%$. The adequacy percentages of protein and carbohydrates for the PSC were more than twice higher than those found in breast milk.

Table 1 - Cumulative percentages by age group, mean and standard deviation of the introduction of the petit-suisse cheese and instant noodles. São Paulo (state of São Paulo), 2010

\begin{tabular}{lccccccc}
\hline & \multicolumn{7}{c}{ Age at introduction (months) } \\
\cline { 2 - 8 } Processed foods & $\mathbf{0 - 6}$ & $\mathbf{7 - 1 2}$ & $\mathbf{1 2 - 3 6}$ & $\begin{array}{c}\text { Not } \\
\text { introduced }\end{array}$ & $\begin{array}{c}\text { Not } \\
\text { informed }\end{array}$ & Total & Mean \pm SD \\
\cline { 2 - 8 } & \% & \% $^{*}$ & \%* $^{*}$ & \% & \% & n & Months \\
\hline Petit-suisse cheese & 48.4 & 89.6 & 97.8 & 2.2 & 0 & 366 & $8.0 \pm 4.2$ \\
Instant noodles & 19.9 & 65.3 & 85.8 & 13.1 & 1.1 & 366 & $11.6 \pm 5.8$ \\
\hline
\end{tabular}

${ }^{*}$ Accumulated percentage; SD: standard deviation 
Table 2 - Proximate nutritional composition and adequacy percentage according to the Recommended Daily Intake by age groups of processed and healthy foods. São Paulo (state of São Paulo), 2010

\begin{tabular}{|c|c|c|c|c|c|c|c|c|}
\hline & \multicolumn{2}{|c|}{$\begin{array}{c}\text { Energy value } \\
\%\end{array}$} & $\begin{array}{c}\text { Protein } \\
\%\end{array}$ & $\begin{array}{c}\text { Total fat } \\
\%\end{array}$ & $\begin{array}{c}\text { Carbohydrate } \\
\%\end{array}$ & $\begin{array}{c}\text { Calcium } \\
\%\end{array}$ & $\begin{array}{c}\text { Iron } \\
\%\end{array}$ & $\begin{array}{c}\text { Sodium } \\
\%\end{array}$ \\
\hline Breast milk & \multicolumn{2}{|c|}{$70 \mathrm{kcal}$} & $1.4 \mathrm{~g}$ & $4.1 \mathrm{~g}$ & $6 g$ & $28 \mathrm{mg}$ & $0.2 \mathrm{mg}$ & $17 \mathrm{mg}$ \\
\hline Age (months) & Male & Female & & & & & & \\
\hline $0-6$ & $12^{*}$ & 13 & 15 & 13 & 10 & 13 & 67 & 14 \\
\hline $7-12$ & 9 & 10 & 13 & 13 & 6 & 10 & 2 & 5 \\
\hline $12-36$ & 7 & 7 & 11 & 13 & 5 & 6 & 3 & 2 \\
\hline Petit-suisse cheese & \multicolumn{2}{|c|}{$121 \mathrm{kcal}$} & $5.8 \mathrm{~g}$ & $2.8 \mathrm{~g}$ & $18 \mathrm{~g}$ & $730.9 \mathrm{mg}$ & $0.1 \mathrm{mg}$ & $412 \mathrm{mg}$ \\
\hline Age (months) & Male & Female & & & & & & \\
\hline $0-6$ & $21^{*}$ & 23 & 64 & 9 & 30 & 348 & 33 & 343 \\
\hline $7-12$ & 17 & 18 & 53 & 9 & 19 & 270 & 1 & 111 \\
\hline $12-36$ & 12 & 12 & 45 & 9 & 14 & 146 & 1.5 & 42 \\
\hline Instant Noodles & \multicolumn{2}{|c|}{$436 \mathrm{kcal}$} & $8.8 \mathrm{~g}$ & $17.1 \mathrm{~g}$ & $62 \mathrm{~g}$ & $18 \mathrm{mg}$ & $0.7 \mathrm{mg}$ & $1.516 \mathrm{mg}$ \\
\hline Age (months) & Male & Female & & & & & & \\
\hline $0-6$ & $76^{*}$ & 84 & 97 & 55 & 103 & 9 & 233 & 1.263 \\
\hline $7-12$ & 59 & 65 & 80 & 57 & 65 & 7 & 6 & 410 \\
\hline $12-36$ & 42 & 44 & 68 & 57 & 48 & 4 & 10 & 152 \\
\hline Savory meal ${ }^{* \star}$ & \multicolumn{2}{|c|}{$130 \mathrm{kcal}$} & $8.1 \mathrm{~g}$ & $3.7 \mathrm{~g}$ & $16 \mathrm{~g}$ & $17.4 \mathrm{mg}$ & $0.4 \mathrm{mg}$ & $8 \mathrm{mg}$ \\
\hline Age (months) & Male & Female & & & & & & \\
\hline $0-6$ & $23^{*}$ & 25 & 89 & 12 & 27 & 9 & 133 & 7 \\
\hline $7-12$ & 18 & 19 & 74 & 12 & 17 & 6 & 4 & 2 \\
\hline $12-36$ & 13 & 13 & 62 & 12 & 12 & 4 & 6 & 1 \\
\hline
\end{tabular}

${ }^{*}$ Adequacy percentage according to the Recommended Daily Intake (RDI) by age groups ${ }^{(16,17) ;}$ ** composition of savory foods: cooked rice; cooked beans; shredded chicken; cooked chopped broccoli; soybean oil ${ }^{(12,13)}$

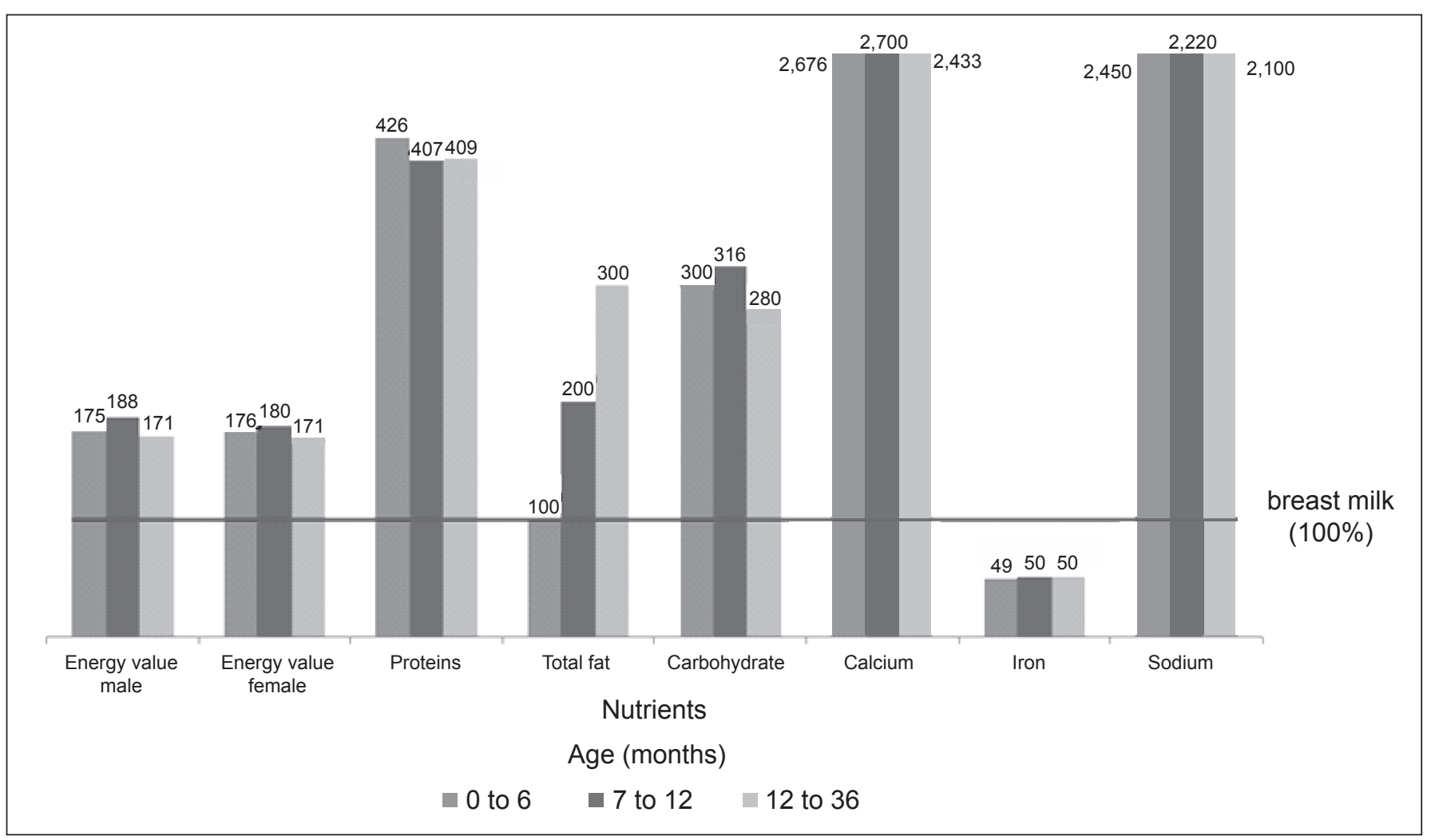

Figure 1 - Adequacy percentages for the de petit-suisse cheese compared to the percentage of breast milk (100\%), by age group. São Paulo (state of São Paulo), 2010 
As for calcium and sodium, the adequacy percentages were more than 20 times higher. Regarding the IN, the percentages of sodium adequacy can be highlighted, which exceed by more than 180 times those found in the savory meal.

\section{Discussion}

This is a cross-sectional study in which the information was reported by mothers/guardians from memory, which can lead to inaccuracies on the period of introduction of foods ${ }^{(18)}$. However, this recall bias may not have substantially influenced the results, since the introduction of these foods in the diet of these children took place a few months before the interview.

The data presented in this study probably reflected the reality of public and philanthropic nurseries in the municipality of São Paulo, since we sought to include daycare centers that represented the universe of these institutions, although we did not adopt probability sampling. In addition, the studied population, although not probabilistically representative of usual consumers in a modern urbanized society such as São Paulo, represents the largest number of children in this society and the highest risk group for dietary mistakes, because they belong to low-income families, whose mothers are predominantly young and with a low education level, which makes them more susceptible to the deleterious influences of the deceptive marketing of processed foods $s^{(9,19)}$.

The present study showed the early introduction of two foods that have nutritional composition unsuitable for infants. The early consumption of obesogenic foods, in the diet of infants, is related to the predisposition for obesity and NCCDs, including diabetes, hypertension and cardiovascular disease ${ }^{(6,7)}$. In addition, the incorporation of these foods into the diet in recent decades has always been associated with misleading advertising campaigns, which promoted the gradual and accelerated incorporation of the petit-suisse cheese and the instant noodles in daily eating habits of families and infants, contrary to the recommended healthy nutritional guidelines for children ${ }^{(2-4,19)}$.

No studies were found that specifically analyzed the chemical composition of these two foods in childhood and its consequences for health and nutrition, which demonstrates the unprecedented character of the present analyses. This research identified that the PSC had already been consumed by $48.4 \%$ of analyzed children before 6 months of life, a period in which the child should be in exclusive breastfeeding.

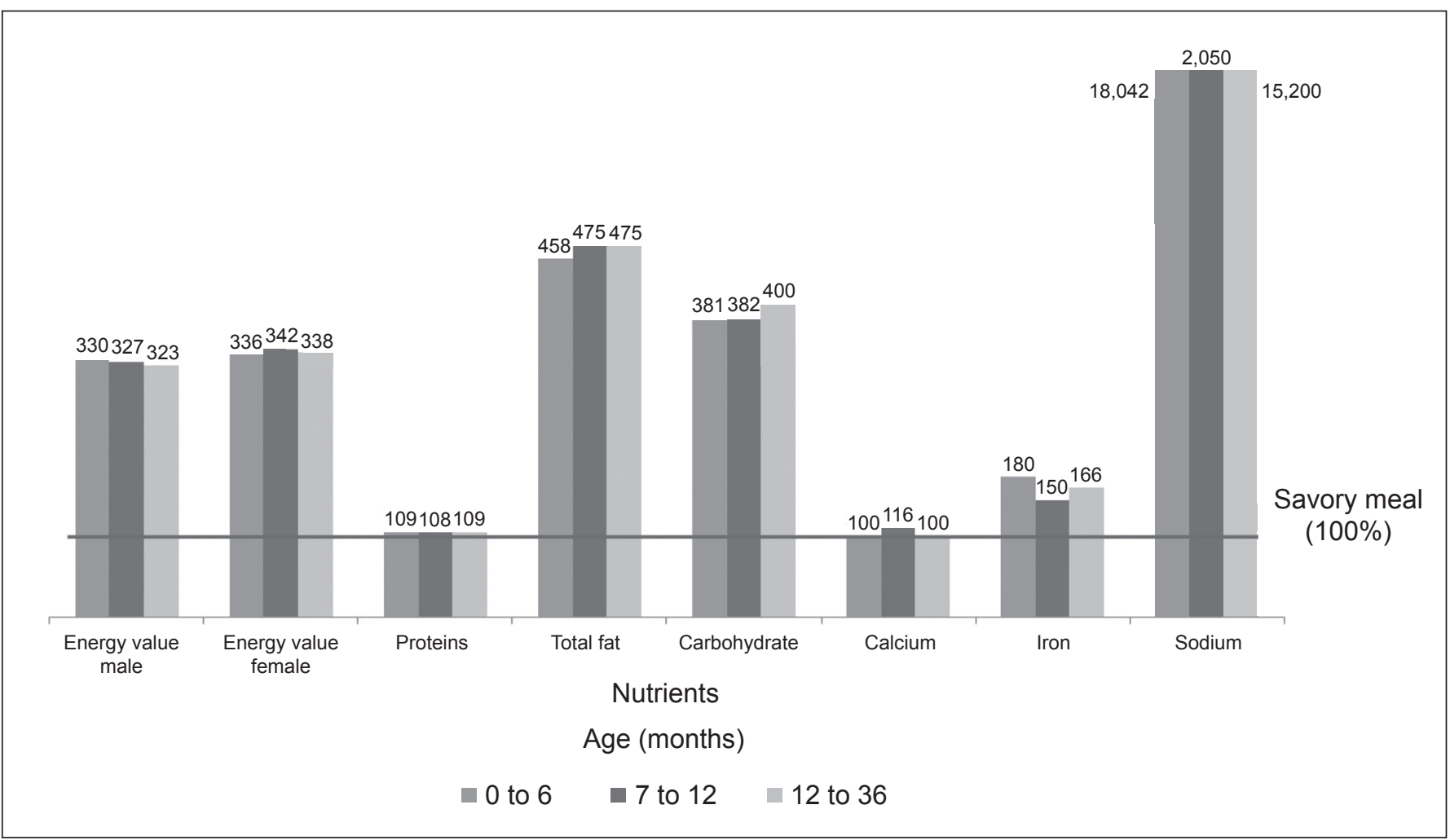

Figure 2 - Percentages of adequacy for the noodles compared to the percentage of adequacy of the savory meal (100\%), by age group. São Paulo (state of São Paulo), 2010 
In the compared analysis of adequacy percentages, we observed that the PSC exceeds by more than $400 \%$ the amount of protein compared to breast milk, which can lead to the development of obesity in school age and in adult life ${ }^{(20)}$.

Also noteworthy are the high amounts of calcium and sodium in the PSC, which exceed by $300 \%$ the daily needs in the age range from zero to 6 months, going far beyond the levels in breast milk. The excessive intake of calcium associated with high sodium intake is even more worrying, since it leads to increased urinary excretion of calcium, causing a negative impact on the child's bone health ${ }^{(21)}$.

Despite the characteristics that make it a very little nutritional food, the sales of the PSC had a significant growth in recent years. The percentage increase in sales from 2009 to 2010 was $14 \%$, being more consumed in the homes of class C, which accounted for $49 \%$ of purchases. The sales revenue of the category in 2010 was in the range of $\mathrm{R} \$ 500$ million to 600 million, and the national annual production increased from 10,000 tons in 1992 to 24,000 tons in $2005^{(22,23)}$.

Due to deceiving advertising, the PSC has been considered a healthy food by families and has become extremely popular after an extensive advertising campaign, which involved health professionals, with the slogan and jingle that marked the history of Brazilian advertising, besides other aggressive and abusive marketing strategies that drove the sales increase, especially for children.

Similarly, the IN was offered early (before 12 months) for more than half the infants and has shown a strong upward trend in consumption, especially in children, because it is perceived as acceptable, with good palatability, and fast preparation $^{(4,19,22)}$. However, in the analysis of Figure 2, it is observed that, in the comparison with the traditional savory meal recommended for children aged from 7 to 12 months, the levels of total fat (>400\%), carbohydrates $(>300 \%)$, energy $(>300 \%)$, and sodium $(>2.000 \%)$ are substantially high, ingredients that, in excess, are harmful to children's health ${ }^{(24-27)}$.

Moreover, the abnormally high intake of calories, identified in this study by high energy values, especially in IN, higher by $300 \%$ in relation to the savory meal, leads to the accumulation of risks for developing obesity and NCCDs, contributing to the increased prevalence of overweight and associated factors in Brazilian infants ${ }^{(6,7,28)}$.

There is evidence in the literature that the early introduction of infant foods cause permanent effects on growth, metabolism, and on the structure or function of an organ (metabolic programming), which predisposes the development of diabetes, hypertension, cardiovascular diseases, and obesity. Inappropriate food habits during periods of high plasticity may alter the chromatin structure and gene expression ${ }^{(7)}$, leading to long-lasting changes in the phenotype and potentially influencing the individual's health, especially regarding the higher susceptibility of developing metabolic syndrome, represented by the increase in the incidence of insulin resistance and hypertension. Therefore, appropriate infant feeding is a crucial component in the prevention of these diseases, since the metabolic programming cannot be reversed ${ }^{(29-31)}$.

However, even in the given context, data about market surveys indicate that the world production of IN, considered the most important Japanese invention in the 20th century, is of 85.6 billion servings per year. In the Brazilian market, instant noodles' overall sales revenues over the last 5 years increased by $31 \%$ in volume and, in 2010 , the sales revenues of the category reached $\mathrm{R} \$ 1.76$ billion. More than $70 \%$ of this product is consumed by the classes $\mathrm{C} / \mathrm{D} / \mathrm{E}$, which are the less instructed and the most susceptible to dietary mistakes. In this situation, the IN is offered by the food industry as an alternative to facilitate consumer's lives, hiding its undesirable nutritional effects. The per capita consumption of this product in 2010 was of $0.9 \mathrm{~kg}$ by inhabitant, reaching $14 \%$ of the national consumption of pasta ${ }^{(22)}$.

Caetano et $a l^{(4)}$, while studying the food practices of healthy infants in three metropolises in Brazil, found similar data, consistent with the findings of this study. The authors highlight the early introduction and the excessive ingestion of some foods, such as PSC and IN, consumed weekly by 29.2 and $12.3 \%$ of children before 6 months, respectively. Other national and international studies that assessed the food consumption of infants also showed the early introduction of processed foods inappropriate for this age range $\mathrm{e}^{(9,32,33)}$.

The data presented here on the PSC and IN are further evidence that the lifestyle of contemporary society leads to early exposure of children to obesogenic and atherogenic foods. Changes in food preparation in the home environment, in the profile of food purchases by families, and in the consumption of pre-prepared meals are striking. This situation reinforces the influence of advertising on the trust that mothers place in products featured in television advertisements, mainly due to lack of knowledge and misinformation about the risks to health and nutrition associated with the continued consumption of these foods $s^{(2,3,8)}$. 
In line with the recommendations of the Brazilian Society of Pediatrics, the Brazilian Ministry of Health, and the descriptions of other surveys conducted in children, the findings of this study showed that the PSC and the IN are inappropriate for consumption by infants. These results indicate the need to include these two foods, largely consumed by children before 36 months, in the norms and nutritional guidelines for parents, guardians, educators, and health professionals, in order to discourage consumption. The isolated orientation that these foods are contraindicated

\section{References}

1. Moodie R, Stuckler D, Monteiro C, Sheron N, Neal B, Thamarangsi T et al. Profits and pandemics: prevention of harmful effects of tobacco, alcohol, and ultra-processed food and drink industries. Lancet 2013;381:670-9.

2. Hawkes $C$. Marketing food to children: changes in the global regulatory environment 2004-2006 [homepage on the Internet]. Genebra: WHO; 2007 [cited 2013 Apr 15]. Available from: http://www.who.int/dietphysicalactivity/ regulatory_environment_CHawkes07.pdf

3. McGinnis JM, Gootman JA, Kraak Vl; Institute of Medicine of the National Academies. Food Marketing to Children and Youth: Threat or Opportunity? Committee on Food Marketing and the Diets of Children and Youth. Washington: The National Academies Press; 2006.

4. Caetano MC, Ortiz TT, Silva SG, Souza FI, Sarni RO. Complementary feeding: inappropriate practices in infants. J Pediatr (Rio J) 2010;86:196-201.

5. Monteiro CA, Levy RB, Claro RM, de Castro IR, Cannon G. Increasing consumption of ultra-processed food and likely impact on human health: evidence from Brazil. Public Health Nutr 2011;14:5-13.

6. Koletzko B, Brands B, Poston L, Godfrey K, Demmelmair H; Early Nutrition Project. Early nutrition programming of long-term health. Proc Nutr Soc 2012;71:371-8.

7. Silveira PP, Portella AK, Goldani MZ, Barbieri MA. Developmental origins of health and disease (DOHaD). J Pediatr (Rio J) 2007;83:494-504.

8. Hawkes $C$. Marketing de alimentos para crianças: o cenário global das regulamentações - Organização Mundial de Saúde. Camargo $C Q$, translator. Brasília: OPAS/ANVISA; 2006.

9. Aquino RC, Philippi ST. Association of children's consumption of processed foods and family income in the city of São Paulo, Brazil. Rev Saude Publica 2002;36:655-60.

10. Konstantyner T, Taddei JA, Oliveira Mde N, Palma D, Colugnati FA. The impact of training for day-care educators on childhood anaemia in nurseries: an institutional randomised clinical trial. Public Health Nutr 2011;14:1450-7.

11. Dean AG, Arner TG, Sangam S, Sunki GG, Friedman R, Lantinga M et al. Epi Info 2000: a database, and statistics program for public health professionals using Windows 95, 98, NT, and 2000 computers. Atlanta: CDC; 2000.

12. Sociedade Brasileira de Pediatria; Departamento de Nutrologia. Obesidade na infância e adolescência: manual de orientação. São Paulo: SBP; 2012.

13. Brasil - Ministério da Saúde. Dez passos para uma alimentação saudável: guia alimentar para crianças menores de 2 anos. Brasília: Ministério da Saúde; 2010.

14. Núcleo de Estudos e Pesquisas em Alimentação; Universidade Estadual de Campinas. Tabela Brasileira de Composição de Alimentos. $4^{\mathrm{a}}$ ed. Campinas: NEPA/Unicamp; 2011.

15. United States Department of Agriculture [homepage on the Internet]. Nutrient Database for Standard Reference [cited 2013 Jul 11]. Available from: http:// ndb.nal.usda.gov/

16. Food and Nutrition Board; Institute of Medicine; National Academies. Dietary reference intakes (DRIs): recommended intakes for individuals, vitamins, foods and nutrition board. Washington: National Academy Press; 2002. for infants, without the specification of the risks involved, such as stated in the eight step of the Food Handbook, has been little effective, because, as demonstrated in this article, the consumption occurs in very high proportions among urban infants from low-income families.

It is necessary to implement public policies to fight obesity and related chronic diseases in the first years of life, as well as to regulate food advertising in Brazil, as it occurs in more developed societies that have clear laws and restrictive marketing that is directed to children.

17. Institute of Medicine of the National Academies. Dietary reference intakes for energy, carbohydrate, fiber, fat, fatty acids, cholesterol, protein, and amino acids. Washington: National Academies Press; 2002.

18. Willett W. Nutritional Epidemiology. $2^{\text {nd }}$ ed. New York: Oxford University Press; 1998.

19. Toloni MH, Longo-Silva G, Goulart RM, Taddei JA. Introduction of processed and traditional foods to the diets of children attending public daycare centers in São Paulo, Brazil. Rev Nutr 2011;24:61-70.

20. Günther AL, Buyken AE, Kroke A. Protein intake during the period of complementary feeding and early childhood and the association with body mass index and percentage body fat at $7 \mathrm{y}$ of age. Am $\mathrm{J}$ Clin Nutr 2007; 85:1626-33.

21. Pereira GA, Genaro PS, Pinheiro MM, Szejnfeld VL, Martini LA. Dietary calcium - strategies to optimize intake. Rev Bras Reumatol 2009;49:164-80.

22. Supermercado Moderno [homepage on the Internet]. Guia Prático de Sortimento macarrão instantâneo [cited 2013 Jul 10]. Available from: http://www2.sm.com.br/ publique/cgi/cgilua.exe/sys/start.htm?sid=15\&busca=Macarr\%E3o

23. SEBRAE [homepage on the Internet]. Estudos de Mercado: Queijos Nacionais [cited 2008 Sep 1]. Available from: http://www.sebrae.com.br/acl_users/ credentials_cookie_auth/require_login?came_from=http\%3A/www.sebrae.com. br/customizado/acesso-a-mercados/sebrae-mercado/estudos-de-mercado

24. Schmidt MI, Duncan BB, Silva GA, Menezes AM, Monteiro CA, Barreto SM et al Doenças crônicas não transmissíveis no Brasil: carga e desafios atuais. Lancet 2001;377:61-74.

25. Salgado CM, Carvalhaes JT. Arterial hypertension in childhood. J Pediatr (Rio J) 2003;79 (Suppl 1):S115-24.

26. World Health Organization. Diet, nutrition and the prevention of chronic diseases. Report of a Joint WHO/FAO Expert Consultation. Geneva: WHO; 2003.

27. Sarno F, Claro RM, Levy RB, Bandoni DH, Ferreira SR, Monteiro CA Estimated sodium intake by the Brazilian population, 2002-2003. Rev Saude Publica 2009;43:219-25.

28. Cocetti M, Taddei JA, Konstantyner T, Konstantyner TC, Barros Filho AA Prevalence and factors associated with overweight among Brazilian children younger than 2 years. J Pediatr (Rio J) 2012;88:503-8.

29. Lillycrop KA, Burdge GC. Epigenetic mechanisms linking early nutrition to long term health. Best Pract Res Clin Endocrinol Metab 2012;26:667-76.

30. Robles RG, Ramírez PA, Velásquez SP. Epigenetics: definition, molecular bases and implications in human health and evolution. Rev Cienc Salud 2012;10:59-71.

31. Srinivasan M, Mahmood S, Patel MS. Metabolic programming effects initiated in the suckling period predisposing for adult-onset obesity cannot be reversed by calorie restriction. Am J Physiol Endocrinol Metab 2013;304:E486-94.

32. Eades SJ, Read AW, McAullay D, McNamara B, O'Dea K, Stanley FJ. Modern and traditional diets for Noongar infants. J Paediatr Child Heatlh 2010; 46:398-403.

33. Grummer-Strawn LM, Scanlon KS, Fein SB. Infant feeding and feeding transitions during the first year of life. Pediatrics 2008;122 (Suppl 2):S36-42. 